Jurnal Manajemen dan Bisnis, Volume 3, No. 1, Juli 2021

\title{
PENGARUH LINGKUNGAN KERJA NON FISIK DAN DISIPLIN KERJA TERHADAP KEPUASAN KERJA PEGAWAI PADA KANTOR CAMAT PALIBELO KABUPATEN BIMA
}

\author{
Vivi Sumanti ${ }^{1}$, Firmansyah ${ }^{2}$ \\ Program Studi Manajemen, STIE Bima, Nusa Tenggara Barat,Indonesia. \\ vivisumanti17.stiebima@gmail.com ${ }^{1}$, firmansyah90.stiebima@gmail.com²
}

\begin{abstract}
ABSTRAK
Penelitian ini bertujuan untuk mengetahui pengaruh lingkungan kerja non fisik dan disiplin kerja terhadap kepuasan kerja pegawai pada Kantor Camat Palibelo Kabupaten Bima. Jenis penelitian yang ditetapkan adalah penelitian penjelasan (explanatory research) dengan pendekatan kuantitatif Sumber data pada penelitian ini adalah data primer. Penelitian ini merupakan penelitian populasi dengan 35 responden pada Kantor Camat Palibelo Kabupaten Bima. Teknik sampling yang digunakan adalah sampling jenuh (total population). Teknik Pengumpulan data penelitian menggunakan metode kuesioner. Metode analisis data menggunakan uji validitas dan reliabilitas, asumsi klasik, regresi linier berganda. Koefisien korelasi, Uji signifikansi menggunakan uji $\mathrm{T}$ dan uji $\mathrm{F}$ dengan taraf signifikansi 5\%. Hasil penelitian menunjukkan bahwa variabel lingkungan kerja non fisik memiliki pengaruh yang signifikan dan menunjukkan hasil positif terhadap kepuasan kerja pgawai. Variabel disiplin kerja berpengaruh positif dan tidak signifikan terhadap kepuasan kerja pegawai. Hasil pengujian dan analisisnya menunjukkan bahwa $\mathrm{F}$ hitung $>\mathrm{F}$ tabel atau 6,781>3,27 dan nilai signifikasi $<0,05$ atau $0,004<0,05$ maka terdapat pengaruh lingkungan kerja non fisik dan disiplin kerja secara simultan sangat signifikan terhadap kepuasan kerja pegawai. Hal ini dibuktikan dengan nilai koefisien korelasi (R) sebesar 0.546 atau 54,6\%, berarti sebesar 54,6\% kontribusi atau pengaruh variabel lingkungan kerja non fisik (X1) dan disiplin kerja (X2) secara simultan (bersama-sama) terhadap variabel Kepuasan kerja (Y), sedangkan sisanya sebesar 45,4\% adalah pengaruh faktor lainnya yang tidak diteliti.
\end{abstract}

Kata Kunci : Lingkungan Kerja Non Fisik, Disiplin Kerja, Kepuasan Kerja

\section{ABSTRACT}

This study aims to determine the effect of non-physical work environment and work discipline on employee job satisfaction at the Palibelo Sub-district Office, Bima Regency. The type of research that is determined is explanatory research with a quantitative approach. The data sources in this study are primary data. This study is a population study with 35 respondents at the Palibelo Sub-district Office, Bima Regency. The sampling technique used is saturated sampling (total population). The technique of collecting research data is using the questionnaire method. Methods of data analysis using validity and reliability tests, classical assumptions, multiple linear regression. Correlation coefficient, significance test using $T$ test and $F$ test with a significance level of 5\%. The results showed that non-physical work environment variables had a significant effect and showed positive results on employee job satisfaction. The work discipline variable has a positive and insignificant effect on employee job satisfaction. The results of the test and analysis show that $F$ count $>F$ table or $6.781>3.27$ and a significance value < 0.05 or $0.004<0.05$, so there is a simultaneous influence of non-physical work environment and work discipline on employee job satisfaction. This is evidenced by the correlation coefficient $(R)$ of 0.546 or $54.6 \%$, meaning $54.6 \%$ of the contribution or influence of non-physical work environment variables (X1) and work discipline (X2) simultaneously (together) on variables Job satisfaction (Y), while the remaining $45.4 \%$ is the influence of other factors not examined.

Keywords: Non-Physical Work Environment, Work Discipline, Job Satisfaction 
Jurnal Manajemen dan Bisnis, Volume 3, No. 1, Juli 2021

\section{PENDAHULUAN}

Keberhasilan organisasi juga tidak terlepas dari kerjasama antara pemimpin dan pegawai, sebab dalam sebuah manajemen instansi/perusahaan diperlukan kolaborasi antara keduanya. Oleh karena itu, Kantor Camat Palibelo Kabupaten Bima harus dapat menciptakan lingkungan kerja non fisik yang kondusif untuk memberikan rasa aman kepada pegawai agar bekerja lebih optimal. Lingkungan kerja akan mempengaruhi emosi pegawai, jika pegawai senang dengan lingkungan yang ada disekitar tempat kerja maka pegawai merasa betah di tempat kerjanya untuk melakukan aktivitas sehingga waktu kerja dipergunakan secara efektif.

Faktor yang menjadi indikasi penyebab utama masalah ketidakpuasan kerja pegawai yaitu lingkungan kerja non fisik dan disiplin kerja. Lingkungan kerja adalah keseluruhan sarana dan prasarana kerja yang ada di sekitar pegawai yang sedang melakukan pekerjaan yang dapat mempengaruhi pelaksanaan pekerjaan (Sutrisno, 2013). Secara garis besar, Lingkungan kerja terbagi dua yaitu : Lingkungan kerja fisik, lingkungan kerja non fisik. Sedarmayanti, (2014) lingkungan kerja non fisik adalah semua keadaan yang terjadi yang berkaitan dengan hubungan kerja, baik hubungan dengan atasan maupun hubungan sesama rekan kerja, ataupun hubungan dengan bawahan. Untuk mengelola hubungan kerja yang baik dengan orang lain maka diperlukan: pengaturan waktu, tahu posisi diri, memahami dampak kata-kata atau tindakan pada diri orang lain. Penerapan hubungan kerja yang baik antar pegawai akan terlihat pada suasana kerja sebagai berikut: Tidak terdapat konflik antar pegawai, setiap pegawai bersemangat dan bergairah dalam menyelesaikan pekerjaan yang menjadi tugasnya, setiap masalah dapat diselesaikan dengan penuh kekeluargaan, pelaksanaan pekerjaan diliputi oleh suasana santai dan keakraban, bukan suasana yang mencekam penuh ancaman dan adanya saling menghargai dan percaya antar pegawai. Hasil penelitian yang dilakukan oleh Handayani (2013) bahwa lingkungan kerja non fisik berpengaruh signifikan terhadap kepuasan kerja pegawai. Hal ini menunjukkan bahwa lingkungan kerja yang kondusif akan meningkatkan suasana pekerjaan yang baik sehingga memiliki tim kerja yang saling mendukung terhadap pekerjaan.

Selain faktor lingkungan kerja non fisik terdapat faktor disiplin kerja yang dapat mempengaruhi kepuasan kerja pegawai yaitu. Disiplin merupakan sarana untuk melatih kepribadian pegawai agar senantiasa menunjukkan kinerja yang baik sikap, perilaku dan pola kehidupan yang baik dan berdisiplin tidak berbentuk dalam waktu yang lama salah satu proses untuk membentuk kepribadian tersebut dilakukan melaui proses latihan. Latihan tersebut dilaksanakan bersama dilaksanakan bersama antar pegawai, 
Jurnal Manajemen dan Bisnis, Volume 3, No. 1, Juli 2021

pimpinan dan selurih personil yang ada dalam organisasi tersebut. Disiplin pegawai negeri sipil telah diatur dalam Peraturan Pemerintah Republik Indonesia nomor 53 tahun 2010. Faktor kedisiplinan memegang peranan yang penting dalam pelaksanaan kerja pegawai. Seorang pegawai yang disiplin tidak akan mencuri waktu kerja untuk melakukan hal-hal lain yang tidak ada kaitannya dengan pekerjaan. Demikian juga pegawai yang mempunyai kedisiplinan akan mentaati peraturan yang ada dalam lingkungan kerja dengan kesadaran yang tinggi tanpa ada rasa paksaan. Pada akhirnya pegawai yang mempunyai kedisiplinan kerja yang tinggi akan mempunyai produktivitas kerja yang baik karena waktu kerja dimanfaatkan sebaik mungkin untuk melaksanakan pekerjaan sesuai dengan target yang telah ditetapkan (Hasibuan, 2014)

Berdasarkan hasil penelitian diketahui bahwa faktor tertinggi yang menyebabkan tidak terciptanya kepuasan kerja pegawai adalah lingkungan kerja non fisik. Faktor kedua adalah disiplin kerja. Kurangnya kepuasan kerja pegawai Camat Palibelo Kabupaten Bima mengakibatkan produktivitas pegawai tidak optimal dan muncul tindakan yang tidak mendukung pekerja mereka. Pegawai bekerja hanya untuk memenuhi kewajiban individu kepada organisasi. Akibatnya, muncul sikap individualis pada pegawai yang menghambat kerja sama antar pegawai. Pegawai tidak memiliki kesadaran secara sukarela untuk membantu rekan kerja yang membutuhkan bantuan pekerjaan, karena merasa pekerjaan tersebut adalah bukan tanggung jawabnya. Dari fenomena tersebut dapat diketahui bahwa faktor yang menjadi indikasi penyebab utama masalah ketidakpuasan kerja pegawai Camat Palibelo Kabupaten Bima adalah masalah lingkungan kerja non fisik dan disiplin kerja. Hal ini ditunjukan dari responden yang mengatakan bahwa penyebab utama masalah kepuasan kerja terletak pada lingkungan kerja non fisik dan disiplin kerja. Hal ini ditunjukan dari prosedur kerja kurang tertata rapi, hubungan antar pegawai yang kurang harmonis, sistem kompensasi dan penghargaan atas prestasi kerja pegawai belum terlaksana dengan baik, akibatnya berdampak pada menurunnya kepuasan kerja pegawai.

Kepuasan kerja menjadi penting dalam suatu perusahaan/intansi karena kepuasan kerja pegawai berkaitan erat dengan hasil kerja pegawai dan kelangsungan hidup organisasi atau instansi yang bersangkutan. Lingkungan kerja merupakan salah satu faktor yang cukup berpengaruh terhadap pekerjaan yang dilakukan oleh pegawai. Lingkungan kerja merupakan segala sesuatu yang ada di sekitar para pegawai dan dapat mempengaruhi dirinya dalam melakukan tugas/pekerjaan yang dibebankan (Nitisemito, 20012). Kondisi lingkungan kerja yang nyaman, aman, dan 
Jurnal Manajemen dan Bisnis, Volume 3, No. 1, Juli 2021

mendukung akan membuat pegawai bersemangat dalam bekerja dan merasa terpenuhi akan kebutuhan-kebutuhan sosial sehingga para pegawai akan cenderung merasa puas dalam bekerja. Lingkungan kerja itu menyangkut lingkungan kerja secara fisik dan lingkungan kerja non fisik. Lingkungan kerja non fisik yang dimaksud adalah faktor sosial lingkungan kerja.

Kedua variabel di atas, yaitu lingkungan kerja non fisik dan kedisiplinan, secara jelas dapat memberikan pengaruh kepada kepuasan kerja pegawai. Jika kedua variabel itu secara sendiri-sendiri dapat mempengaruhi kepuasan kerja, maka secara bersama-sama pula dapat mempengaruhi kepuasan kerja pegawai. Penelitian yang dilakukan oleh Noor Rika Dinata Inbar, dkk (2018) bahwa terdapat pengaruh yang signifikan dari lingkungan kerja terhadap disiplin kerja serta lingkungan kerja terhadap semangat kerja pegawai.

Masalah disiplin kerja pegawai pada kantor Camat Palibelo terletak pada pekerjaan pegawai yang monoton dan tidak jelasnya tugas dan karakteristik kerja pegawai serta penempatan pegawai yang tidak sesuai dengan bidang dan keahlian yang dimiliki oleh pegawai.. Akibatnya pegawai sering melakukan berbagai pelanggaran kedisiplinan. Hal itu terlihat dengan masih adanya pegawai yang masuk terlambat kerja, pulang tidak sesuai waktu. Selain itu pegawai sering mengulur waktu istirahat. Apabila hal ini terus-menerus, maka dapat merugikan bagi instansi serta masih terdapat pegawai yang bersantai dan keluar tanpa ijin pada saat jam kerja sehingga waktu terbuang percuma dapat menyebabkan pekerjaan yang dihasilkan tidak maksimal.

Dari uraian latar belakang di atas, faktor lingkungan kerja non fisik dan disiplin kerja diindikasikan menjadi masalah utama yang mempengaruhi kepuasan kerja. Oleh karena itu, penulis tertarik melakukan penelitian terhadap pengaruh lingkungan kerja non fisik dan disiplin kerja terhadap kepuasan kerja pegawai pada Kantor Camat Palibelo Kabupaten Bima dengan tujuan untuk mengetahui besarnya pengaruh lingkungan kerja non fisik dan disiplin kerja terhadap kepuasan kerja pegawai pada Kantor Camat Palibelo Kabupaten Bima.

\section{KAJIAN TEORI}

\subsection{Teori Lingkungan Kerja Non Fisik}

Lingkungan kerja non fisik adalah semua keadaan yang terjadi yang berkaitan dengan hubungan kerja, baik hubungan dengan atasan maupun hubungan sesama reakan kerja, ataupun hubungan dengan bawahan. Lingkungan non fisik ini juga merupakan kelompok lingkungan kerja yang tidak bisa diabaikan. Wursanto (2011) mendefinisikan lingkungan kerja non fisik sebagai "sesuatu yang menyangkut segi psikis dari lingkungan 
Jurnal Manajemen dan Bisnis, Volume 3, No. 1, Juli 2021

kerja”. Kemudian menurut Robbins (2015) lingkungan kerja non fisik adalah upah dan tunjangan tambahan bukanlah alasan utama individu menyukai pekerjaan mereka atau tetap bersama seorang pemberi kerja, yang jauh lebih penting adalah kualitas pekerjaan pegawai dan kesuportifan lingkungan kerja. Jadi memiliki manajer dengan keahlian antarpersonal yang bagus cenderung menjadikan tempat kerja lebih menyenangkan, membuat lebih mudah untuk memperkerjakan dan mempertahankan individu yang berkualitas. Dari penjelasan diatas, disimpulkan bahwa lingkungan kerja non fisik, merupakan lingkungan kerja yang berwujud tidak nyata, namun keberadaanya dapat dirasakan. Wujud dari lingkungan kerja tersebut antara lain komunikasi yang antar sesama pegawai, atasan, maupun bawahan, demi terciptanya suatu kondisi lingkungan pekerjaan yang baik dan nyaman.

Lingkungan kerja non fisik dapat dipengaruhi oleh beberapa faktor. Adapun aaktor-faktor lingkungan kerja non fisik menurut Robbins (2015), antara lain:

1. Hubungan kerja pegawai (bawahan) dengan manajer (atasan)

Hubungan kerja yang baik antara pegawai dengan manajer akan mempengaruhi semangat kerja pegawai dan kepuasan kerja pegawai. Kerjasama antara pegawai dengan manajer harus diupayakan sedemikian rupa sehingga tercipta kerjasama yang baik.

2. Hubungan kerja pegawai dengan rekan kerja

Rekan kerja yang mampu diajak kerjasama dan mendukung dalam pelaksanaan kerja cenderung berpengaruh terhadap penyelesaian pekerjaan yang dibebankan kepada mereka dan kepuasan kerja pada pegawai tersebut.

Lingkungan kerja non fisik adalah semua keadaan yang terjadi yang berkaitan dengan hubungan kerja. Sedarmayanti, (2014) bahwa di dalam lingkungan kerja non fisik, ada beberapa aspek dan indikator yang bisa mempengaruhi perilaku pegawai, seperti:

1. Tanggung jawab kerja

Dengan tanggung jawab kerja, maka pegawai tahu apa saja tanggung jawab mereka selama berada di dalam perusahaan. Dimulai dari tugas kerja, hasil kerja, hingga sikap yang mereka tampilkan di dalam.

2. Struktur kerja adalah pekerjaan yang diberikan kepada pegawai memang sudah berada di dalam struktur kerja serta organisasi yang baik. Dengan begitu, pekerjaan yang ada sudah sesuai dengan apa yang dibutuhkan.

3. Kelancaran komunikasi adalah bagian yang penting di dalam menjalankan pekerjaan. Dengan begitu, pegawai harus merasa ada komunikasi yang baik, lancar, serta terbuka di antara rekan kerja hingga atasan. 
Jurnal Manajemen dan Bisnis, Volume 3, No. 1, Juli 2021

4. Kerja sama antar kelompok Pegawai harus merasa adanya kerja sama antar kelompok yang baik. Inilah yang membuat pekerjaan bisa dilakukan dengan lebih lancar dan mudah.

\subsection{Teori Disiplin Kerja}

Simamora (2015) berpendapat, disiplin adalah prosedur yang mengoreksi atau menghukum bawahan karena melanggar peraturan atau prosedur. Disiplin merupakan bentuk pengendalian diri pegawai dan pelaksanaan yang teratur dan menunjukkan tingkat kesungguhan tim kerja di dalam suatu organisasi. Sedangkan Keith Davis dalam Mangkunegara (2012) mengemukakan bahwa disiplin merupakan tindakan manajemen untuk menegakkan peraturan-peraturan maupun standar dari organisasi tersebut. Jadi disiplin kerja merupakan ketetapan atau peraturan yang telah ditetapkan oleh suatu organisasi, dan para anggota atau pegawai diharuskan memiliki kesadaran dan kesedian dalam menaati segala peraturan dan norma-norma yang ada dalam organisasi Menurut Sutrisno (2016) faktor yang memengaruhi disiplin kerja adalah sebagai berikut :

1. Besar kecilnya pemberian kompensasi

2. Ada tidaknya keteladanan pimpinan dalam organisasi

3. Ada tidaknya aturan pasti yang dapat dijadikan pegangan

4. Keberanian pimpinan dalam mengambil tindakan
5. Ada tidaknya pengawasan pimpinan

6. Ada tidaknya perhatian kepada para pegawai

7. Diciptakan kebiasaan-kebiasaan yang mendukung tegaknya disiplin

Disiplin kerja merupakan sikap mental yang tercermin dalam perbuatan atau tingkah laku perorangan atau kelompok berupa kepatuhan atau ketaatan terhadap peraturanperaturan yang di tetapkan. Hasibuan, (2014) mengemukakan bahwa indikator kedisiplinan kerja pegawai adalah sebagai berikut:

1. Tujuan dan kemampuan. Tujuan dan kemampuan dapat mempengaruhi kedisiplinan pegawai, karena tujuan yang akan dicapai harus jelas dan ditetapkan secara ideal serta cukup menantang bagi kemampuan pegawai..

2. Teladan pimpinan. Teladan pimpinan sangat berperan dalam menentukan kedisiplinan pegawai karena pemimpin dijadikan teladan dan panutan oleh para bawahannya. Pimpinan harus memberi contoh yang baik kedisipinan, baik, jujur, adil serta sesuai kata dengan perbuatannya..

3. Balas Jasa. Balas jasa juga ikut mempengaruhi kedisiplinan pegawai karena balas jasa akan memberikan kepuasan dan kecintaan pegawai terhadap pekerjaanya. Jika kecintaan pegawai semakin baik terhadap pekerjaan, kedisiplinan mereka akan semakin baik. 
Jurnal Manajemen dan Bisnis, Volume 3, No. 1, Juli 2021

4. Keadlilan. Keadilan ikut mendorong terwujudnya kedisiplinan pegawai, karena ego dan sifat manusia yang selalu merasa dirinya penting dan minta diperlakukan sama dengan manusia lainnya.

5. Waskat. (pengawasan melekat) adalah tindakan nyata dan paling efektif dalam mewujudkan kedisiplinan pegawai. Dengan waskat berarti atasan harus aktif dan langsung mengatasi perilaku, moral, sikap, gairah kerja dan prestasi kerja bawahannya.

6. Sanksi Hukuman. Sanksi hukuman berperan penting dalam memelihara kedisplinan pegawai. Dengan sanksi hukuman yang sangat berat, pegawai akan semaskin takut melanggar peraturanperaturan perusahaan, sikap, dan perilaku indispliner pegawai akan berkurang.

7. Ketegasan. Pimpinan dalam melakukan tindakan akan mempengaruhi kedisplinan pegawai. Ketegasan pimpinan menegur dan menghukum pegawai yang indispliner akan mewujudkan kedisplinan yang baik pada organisasi.

\subsection{Kepuasan Kerja}

Robbins (2015) disebutkan bahwa kepuasan kerja adalah suatu sikap umum terhadap pekerjaan seseorang sebagai perbedaan antara banyaknya ganjaran yang diterima pekerja dengan banyaknya ganjaran yang diyakini seharusnya diterima. Kepuasan kerja merupakan hal penting yang dimiliki individu di dalam bekerja. Setiap individu pekerja memiliki karakteristik yang berbeda beda, maka tingkat kepuasan kerjanya pun berbeda - beda pula tinggi rendahya kepuasan kerja tersebut dapat memberikan dampakyang tidak sama.

Menurut Priansa (2014) kepuasan kerja merupakan perasaan pegawai terhadap pekerjaannya, apakah senang / suka atau tidak senang/tidak suka sebagai hasil interaksi pegawai dengan lingkungan pekerjaannya atau sebagai presepsi sikap mental, juga sebagai hasil penilaian pegawai terhadap pekerjaannya. Perasaan pegawai terhadap pekerjaannya mencerminkan sikap dan perilakunya dalam bekerja.

Menurut Rivai (2011) menyatakan faktor-faktor yang biasanya digunakan untuk mengukur kepuasan kerja seorang pegawai adalah:

1. Faktor Individu. Faktor ini meliputi usia pegawai, kesehatan, kecerdasan (IQ), latar belakang pendidikan, emosi, sikap kerja, pola pikir, dan kepribadian.

2. Faktor Intrinsik Pekerjaan. Faktor ini meliputi atribut kerja yang mengharuskan pegawai memiliki skill khusus, tingkat kesulitan pekerjaan, kebanggaan atas suatu pekerjaan.

3. Gaji dan Fasilitas. Faktor penghasilan seringkali berpengaruh pada tingkat kepuasan kerja seorang pegawai. Selain itu, fasilitas jaminan kesehatan, jaminan hari 
Jurnal Manajemen dan Bisnis, Volume 3, No. 1, Juli 2021

tua, dan rumah, juga menjadi faktor yang mempengaruhi kepuasan kerja.

4. Pengawasan/Penyeliaan sangat berpengaruh terhadap tingkat kepuasan kerja seorang pekerja. Supervisi yang buruk dapat mengakibatkan hasil kerja yang tidak maksimal dan tingginya turnover.

5. Rekan Kerja dan Sosial. Hubungan dengan rekan kerja sejawat juga berperan terhadap tingkat kepuasan kerja seseorang. Seringkali kualitas hubungan dengan rekan kerja berpengaruh pada hasil kerja para pegawai..

6. Kondisi Kerja. Faktor ini meliputi situasi dan kondisi kerja. Keamanan kerja juga menjadi faktor penting dalam menunjang kepuasan kerja karena mempengaruhi perasaan selama bekerja di suatu tempat.

Kepuasan kerja mencerminkan perasaan seseorang terhadap pekerjaannya.Ini nampak dalam sikap positif pegawai terhadap pekerjaaan dan segala sesuatu yang dihadapi dilingkungan kerjanya. Kepuasan kerja ini sendiri mengandung beberapa aspek yang berpengaruh dengan kepuasan kerja itu sendiri, (dikutip dari Tugas Suhandito, 2013) indikator dari kepuasan kerja pegawai adalah : 1) Kepuasan terhadap Pekerjaan itu sendiri, 2) Kepuasan terhadap Rekan kerja. 3) Kepuasan terhadap Promosi jabatan dan 4) Kepuasan terhadap Supervisior atau atasan

\subsection{Keterkaitan antar Variabel}

\section{Pengaruh Lingkungan Kerja Non Fisik Terhadap Kepuasan Kerja}

Lingkungan kerja non fisik merupakan konsep yang sangat penting bagi para pegawai untuk mendukung mereka dalam menyelesaikan suatu pekerjaan secara sukses sehingga tujuan organisasi dapat tercapai. Dengan lingkungan kerja non fisik yang kondusif mampu memberikan dorongan, dan dukungan untuk mencapai kepuasan kerja pegawai (Nitisemito, 2013). Lingkungan kerja non fisik yang kondusif dapat berpengaruh langsung terhadap pegawai dalam meningkatkan kepuasan kerja pegawai. Sebaliknya lingkungan kerja yang tidak memadai akan dapat menurunkan kepuasan kerja pegawai. Jadi terlihat jelas bahwa lingkungan kerja non fisik yang baik akan mempengaruhi kepuasan kerja pegawai.

Dengan menciptakan lingkungan kerja non fisik yang nyaman, dimana hubungan antar rekan kerja yang harmonis akan mampu memicu terjalinnya kerja sama kerja pegawai yang baik dalam melaksanakan tugastugasnya. Dalam hal ini lingkungan kerja diindikasikan memiliki pengaruh positif terhadap kepuasan kerja pegawai. Penelitian yang dilakukan oleh Handayani (2013) bahwa lingkungan kerja non fisik berpengaruh signifikan terhadap kepuasan kerja pegawai. Hal ini menunjukkan bahwa lingkungan kerja yang kondusif akan meningkatkan suasana 
Jurnal Manajemen dan Bisnis, Volume 3, No. 1, Juli 2021

pekerjaan yang baik sehingga memiliki tim kerja yang saling mendukung terhadap pekerjaan. Penelitian yang dilakukan oleh Ni Nyoman Paramita Iswari Putri Pande (2013) menyebutkan bahwa adanya pengaruh yang positif dan signifikan antara lingkungan kerja non fisik dengan kepuasan kerja pegawai. Berdasarkan teori dan penelitian terdahuli, maka dapat diajukan hipotesis sebagai berikut:

H1 Lingkungan Kerja Non Fisik
berpengaruh positif dan signifikan
terhadap Kepuasan Kerja

\section{Pengaruh Disiplin Kerja Terhadap}

\section{Kepuasan Kerja}

Disiplin kerja diartikan sebagai suatu sikap, tingkah laku, dan perbuatan yang sesuai peraturan dari organisasi dalam bentuk tertulis maupun tidak. Oleh karena itu, dalam praktiknya bila suatu organisasi telah mengupayakan sebagian besar peraturanperaturan yang ditaati sebagian besar pegawai, maka kedisiplinan telah dapat ditegakkan (Darmawan, 2013: 41). Pada dasarnya setiap pegawai dituntut untuk memiliki sikap disiplin yang tinggi, dengan contoh hadir tepat waktu di kantor, meninggalkan meja kerja setelah jam pulang kantor, mengerjakan tugas yang diberikan agar mencapai target yang telah ditentukan. Dari kedisiplinan pegawai yang tinggi maka akan muncul tingkat kepuasan pegawai dalam bekerja. Pegawai maupun atasan akan merasa puas apabila pegawai mengerjakan tugas sesuai dengan target yang sudah ditentukan. Hal ini mengindikasikan bahwa disiplin kerja memiliki pengaruh positif terhadap kepuasan kerja. Berdasarkan teori di atas, maka dapat diajukan hipotesis sebagai berikut:

$\mathrm{H} 2$ : Disiplin kerja berpengaruh positif dan signifikan terhadap Kepuasan Kerja Pegawai

\section{Pengaruh Lingkungan Kerja Non Fisik} dan Disiplin Terhadap Kepuasan Kerja

Pengaruh lingkungan kerja non fisik yang baik akan menuntut pegawai mempunyai disiplin kerja yang tinggi dan otomatis akan terjalin kerja sama yang baik dalam organisasi sehingga akan berpengaruh pada kepuasan kerja pegawai. Tetapi, apabila lingkungan kerja non fisik yang ada di sekeliling pegawai buruk maka akan menyebabkan rendahnya disiplin kerja sehingga kepuasan kerja akan menurun. Menurut Ishak dan Tanjung (2013) manfaat lingkungan kerja non fisik adalah menciptakan hubungan yang baik sesama pegawai maupun dengan pimpinan sehingga produktivitas dan semangat kerja meningkat. Kondisi lingkungan kerja non fisik yang nyaman, aman, dan sesuai dengan jenis pekerjaan akan mendorong pegawai untuk bekerja sebaik mungkin dalam usaha mencapai tujuan organisasi.

Kedua variabel di atas, yaitu lingkungan kerja non fisik dan kedisiplinan, secara jelas dapat memberikan pengaruh kepada kepuasan kerja pegawai. Jika kedua variabel itu secara 
Jurnal Manajemen dan Bisnis, Volume 3, No. 1, Juli 2021

sendiri-sendiri dapat mempengaruhi kepuasan kerja, maka secara bersama-sama pula dapat mempengaruhi kepuasan kerja pegawai. Penelitian yang dilakukan oleh Noor Rika Dinata Inbar, dkk (2018) bahwa terdapat pengaruh yang signifikan dari lingkungan kerja terhadap disiplin kerja serta lingkungan kerja terhadap semangat kerja pegawai. Berdasarkan teori dan penelitian terdahuli, maka dapat diajukan hipotesis sebagai berikut: H3 : Lingkungan Kerja Non Fisik dan Disiplin kerja berpengaruh positif dan signifikan terhadap Kepuasan Kerja

\subsection{Kerangka Pikir}

Kerangka pemikirian penelitian bertujuan memberi gambaran tentang hubungan antar variabel. Berdasarkan teoriteori variabel penelitian, hubungan antar variabel, dan penelitian terdahulu yang difokuskan pada perumusan masalah maka kerangka pemikiran yang akan diterapkan dalam penelitian ini sebagai berikut:

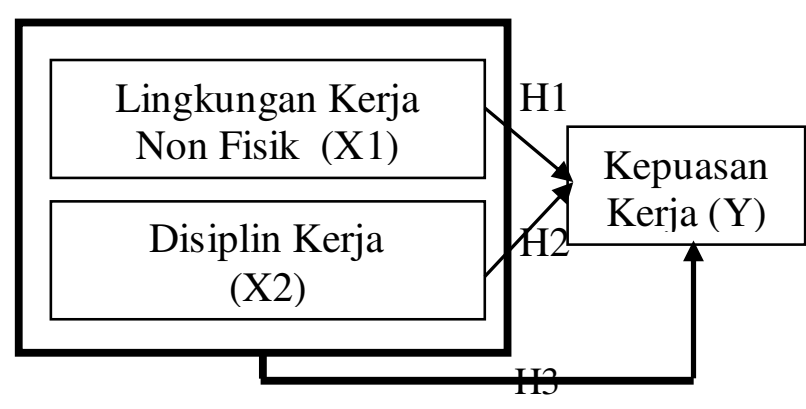

Gambar 1. Kerangka Berpikir Keterangan :

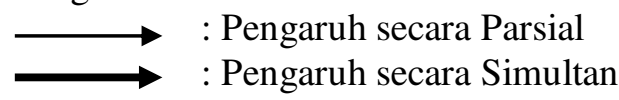

\section{METODE PENELITIAN}

Jenis penelitian yang ditetapkan adalah penelitian penjelasan (explanatory research) dengan pendekatan kuantitatif. Penelitian ini bertujuan untuk menjelaskan seberapa besar pengaruh lingkungan kerja non fisik dan disiplin kerja terhadap kepuasan kerja sesuai fakta-fakta yang ada. Populasi pada penelitian ini adalah pegawai pada Kantor Camat Palibelo Kabupaten Bima dalam berbagai jenjang jabatan yang berjumlah 35 orang yang terdiri dari PNS 16 orang dan Honorer Daerah 19 orang. Teknik sampling yang digunakan adalah teknik sampling jenuh (total population). Dengan demikian jumlah sampel pada penelitian ini adalah berjumlah 35 orang. Instrumen yang digunakan dalam penelitian ini adalah kuesioner. Skala pengukuran yang digunakan dalam penelitian ini adalah menggunakan skala likert. Skala ini biasanya menggunakan skala 1-5 yang memiliki nilai ujung yang menyatakan sangat setuju dan sangat tidak setuju. Teknik pengumpulan data diperoleh dengan metode kuisioner yang telah diuji validitas dan reliabilitasnya.

Teknik yang digunakan untuk melakukan uji validitas adalah uji validitas convergent. Validitas convergent berhubungan dengan prinsip bahwa pengukur-pengukur dari suatu konstruk seharusnya berkorelasi tinggi. Uji validitas diberikan kepada 35 orang responden. Instrumen dinyatakan valid jika 
Jurnal Manajemen dan Bisnis, Volume 3, No. 1, Juli 2021

memiliki nilai korelasi antara skor butir dengan skor total lebih dari 0,30 (Sugiyono, 2016). Uji reliabilitas dimaksudkan untuk mengetahui keandalan dari jawaban terhadap pernyataan. Teknik yang digunakan untuk menguji reliabilitas instrumen dalam penelitian ini adalah Cronbach Alpha $(\alpha)$. Cronboach Alpha adalah koefisien keandalan yang menunjukkan seberapa baik item dalam suatu kumpulan secara positif berkorelasi satu sama lain. Suatu konstruk atau variabel dikatakan reliabel jika memberikan nilai cronbach alpha lebih besar dari 0,60.

Teknik analisis data menggunakan Uji asumsi klasik yang terdiri dari Uji Normalitas, Uji Multikolinearitas, Uji Autokorelasi dan Uji Heteroskedastisitas. Analisis Regresi Linier Berganda, Koefisien Korelasi, Koefisien Determinasi, Uji Hipotesis yang terdiri dari Uji Hipotesis Parsial (Uji T) digunakan untuk mengetahui apakah masing-masing variabel bebas secara parsial mempunyai pengaruh yang signifikan terhadap variabel terikat. Kriteria pengukuran signifikan atau tidanya yaitu jika nilai signifikan ( $\mathrm{sig}>0,05)$, nilai thitung tidak signifikan dan Jika nilai signifikan (sig < 0,05), nilai t-hitung signifikan dan $\mathrm{Uji}$ Hipotesis Simultan (Uji F) yaitu suatu uji untuk mengetahui pengaruh variabel lingkungan kerja non fisik (X1) dan disiplin kerja (X2) secara simultan terhadap kepuasan kerja pegawai (Y). dengan menggunakan bantuan SPSS Versi 23.0 (Ghozali, 2016).

\section{HASIL DAN PEMBAHASAN}

\subsection{Analisis Dekriptif}

Berdasarkan hasil analisis data, maka didapat hasil perhitungan statistik berdasarkan jenis kelamin, umur dan status kpegawaian subjek penelitian maka diperoleh gambaran sebagai berikut:

Tabel 1 : Profil Responden

\begin{tabular}{|c|c|c|}
\hline $\begin{array}{c}\text { Karakteristik } \\
\text { Responden }\end{array}$ & Jumlah & $\begin{array}{c}\text { Porsentase } \\
(\%)\end{array}$ \\
\hline \multicolumn{2}{|c|}{ Jenis Kelamin } & \\
\hline Laki-Laki & 21 & $60 \%$ \\
Perempuan & 14 & $40 \%$ \\
\hline \multicolumn{2}{|c|}{ Umur } & $23 \%$ \\
\hline $25-30$ & 8 & $29 \%$ \\
$31-40$ & 10 & $43 \%$ \\
$40-50$ & 15 & $6 \%$ \\
\hline$>50$ & 2 & $46 \%$ \\
\hline Status Kepegawaian & $54 \%$ \\
\hline PNS & 16 & \\
\hline Honor & 19 & \\
\hline
\end{tabular}

Sumber : Data Primer, diolah 2021

Berdasarkan tabel 1 di atas jumlah responden adalah 35 yang terdiri dari 21 a ta u $60 \%$ berjenis kelamin laki-laki dan 14 orang atau $40 \%$ berjenis kelamin perempuan. Pada bagian umur terdapat $23 \%$ berumur 25-30 tahun, $29 \%$ berumur $31-40,43 \%$ berumur antara $40-50$ dan $6 \%$ berumur $>50$ tahun. Sedangkan informasi status kepegawaian sebanyak $46 \%$ merupakan PNS dan 54\% adalah Pegawai Honor.

\subsection{Uji Validitas dan Reliabilitas}

Besarnya $r$ tiap butir pertanyaan dapat dilihat pada kolom Corrected items. Hasil uji validitas untuk instrumen penelitian adalah sebagai berikut :

Tabel 1. Hasil Uji Validitas 
Jurnal Manajemen dan Bisnis, Volume 3, No. 1, Juli 2021

\begin{tabular}{|c|c|c|}
\hline Variabel X1 & $\begin{array}{c}\text { Total } \\
\text { Correlations }\end{array}$ & Keterangan \\
\hline Soal 1 & 0,546 & Valid \\
\hline Soal 2 & 0,681 & Valid \\
\hline Soal 3 & 0,710 & Valid \\
\hline Soal 4 & 0,421 & Valid \\
\hline Soal 5 & 0,709 & Valid \\
\hline Soal 6 & 0,681 & Valid \\
\hline Soal 7 & 0,481 & Valid \\
\hline Soal 8 & 0,378 & Valid \\
\hline Variabel X2 & Total & Keterangan \\
\hline Soal 1 & 0,370 & Valid \\
\hline Soal 2 & 0,797 & Valid \\
\hline Soal 3 & 0,715 & Valid \\
\hline Soal 4 & 0,636 & Valid \\
\hline Soal 5 & 0,556 & Valid \\
\hline Soal 6 & 0,541 & Valid \\
\hline Soal 7 & 0,557 & Valid \\
\hline Soal 8 & 0,662 & Valid \\
\hline Variabel Y & Total & Keterangan \\
\hline Soal 1 & 0,661 & Valid \\
\hline Soal 2 & 0,537 & Valid \\
\hline Soal 3 & 0,369 & Valid \\
\hline Soal 4 & 0,389 & Valid \\
\hline Soal 5 & 0,688 & Valid \\
\hline Soal 6 & 0,716 & Valid \\
\hline Soal 7 & 0,526 & Valid \\
\hline Soal 8 & 0,593 & \\
\hline
\end{tabular}

Sumber : Output SPSS, diolah, 2021

Hasil uji validitas terhadap variabel Lingkungan Kerja Non Fisik, Disiplin Kerja dan Kepuasan Kerja pada output SPSS (Lampiran) yang disajikan pada nilai korelasi $\left(\mathrm{r}_{\mathrm{x \gamma}}\right)$ untuk item pertanyaan no 1,2,3,4,5,6,7,8, memiliki nilai corrected item total correlation $>0.3$. Dengan demikian butir soal / pernyataan tersebut dinyatakan valid sehingga dapat digunakan dalam penelitian ini.

Suatu kuisioner dikatakan reliabel atau handal jika jawaban seseorang terhadap pernyataan adalah konsisten atau stabil dari waktu ke waktu. Untuk mengetahui uji ini menggunakan nilai Cronbach Alpha, kuesioner dikatakan reliabel jika nilai dari Cronbach Alpha di atas 0,60. Hasil uji reliabilitas adalah sebagai berikut :

Tabel 2. Hasil Uji Reliabilitas

\begin{tabular}{|c|c|c|c|}
\hline Variabel & $\begin{array}{c}\text { Cronbach } \\
\text { Alpha }\end{array}$ & $\begin{array}{c}\text { Standar } \\
\text { Reliabilitas }\end{array}$ & Ket \\
\hline $\begin{array}{c}\text { Lingkungan } \\
\text { Kerja Non } \\
\text { Fisik }\end{array}$ & 0,725 & 0,600 & Reliable \\
\hline Disiplin Kerja & 0,741 & 0,600 & Reliable \\
\hline $\begin{array}{c}\text { Kepuasan } \\
\text { Kerja }\end{array}$ & 0,672 & 0,600 & Reliable \\
\hline
\end{tabular}

Sumber : Hasil Penelitian, diolah 2021

Pada tabel di atas, terlihat bahwa nilai koefisien Cronbach Alpha dari variabel Lingkungan Kerja Non Fisik, Disiplin kerja dan kepuasan kerja menunjukkan hasil yang beragam dan memiliki nilai koefisien Cronbach Alpha rata-rata lebih besar dari 0,600 artinya alat ukur yang digunakan pada masing-masing variabel penelitian dinyatakan reliable atau layak digunakan sebagai alat ukur dalam penelitian ini. Nilai koefisien cronbach 's alpha dari ketiga variabel tersebut mendekati 1 menandakan reliabilitas dengan konsistensi yang tinggi. Dengan demikian data yang diperoleh pada penelitian ini layak digunakan pada analisa selanjutnya.

\subsection{Uji Asumsi Klasik}

\section{Uji Normalitas}

Pengujian normalitas pada penelitian ini, menggunakan uji kolmogorov-smirnov test. Hasil uji normalitas ditunjukkan pada tabel berikut: 
Jurnal Manajemen dan Bisnis, Volume 3, No. 1, Juli 2021

Tabel 3. Hasil Uji Normalitas

One-Sample Kolmogorov-Smirnov Test

\begin{tabular}{|ll|r|r|r|}
\hline & & \multicolumn{1}{|c|}{ X1 } & \multicolumn{1}{|c|}{ X2 } & \multicolumn{1}{c|}{$\mathrm{Y}$} \\
\hline $\mathrm{N}$ & & 35 & 35 & 35 \\
Normal Parameters $^{\mathrm{a}}{ }^{2}$ & Mean & 29.0857 & 32.6000 & 33.9429 \\
& Std. Deviation & 3.05221 & 3.54135 & 2.83821 \\
Most Extreme & Absolute & .135 & .110 & .131 \\
Differences & Positive & .130 & .110 & .107 \\
& Negative & -.135 & -.064 & -.131 \\
Kolmogorov-Smirnov Z & .797 & .652 & .775 \\
Asymp. Sig. (2-tailed) & .549 & .790 & .586 \\
\hline
\end{tabular}

a. Test distribution is Normal.

Sumber : Hasil Penelitian, diolah 2021

Uji normalitas dengan uji Kolmogorov Smirnov dapat diketahui bahwa variabel variabel X1 memiliki nilai sebesar 0,549, variabel variabel X2 memiliki nilai 0,790 dan variabel variabel $\mathrm{Y}$ memiliki nilai 0,586. Dengan demikian dapat disimpulkan bahwa seluruh data pada penelitian ini berdistribusi normal. Hal ini dapat dilihat dari tingkat signifikansi seluruh variabel adalah diatas 0,05 seehingga data pada penelitian ini mempunyai distribusi yang normal artinya data penelitian menyebar merata di wilayah normalitas.

\section{Uji Multikolinieritas}

Untuk mendeteksi ada tidaknya multikolinieritas dapat dilihat pada nilai tolerance dan VIF. Hasil uji multikolinieritas dapat disajikan pada tabel di bawah ini:

Tabel 4 : Hasil Uji Multikolinearitas

\begin{tabular}{|c|c|c|c|}
\hline \multicolumn{4}{|c|}{ Coefficients $^{\text {a }}$} \\
\hline \multirow[b]{2}{*}{ Model } & & \multicolumn{2}{|c|}{ Collinearity Statistics } \\
\hline & & Tolerance & VIF \\
\hline \multirow[t]{3}{*}{1} & (Constant) & & \\
\hline & $\mathrm{X} 1$ & .810 & 1.235 \\
\hline & $\mathrm{X} 2$ & .810 & 1.235 \\
\hline
\end{tabular}

a. Dependent Variable: Y

Sumber : Hasil Penelitian, diolah 2021
Dari hasil analisis pada tabel di atas terlihat bahwa variabel bebas (independent) dalam penelitian ini memiliki nilai VIF-nya di bawah 10 dan nilai tolerance yang bernilai 1 . Hal ini bahwa tidak terjadi multikolinearitas antara variabel bebas. Dengan demikian, dapat disimpulkan bahwa variabel bebas (independent) memenuhi persyaratan asumsi klasik sehingga tidak terjadi multikolinieritas.

\section{Uji Autokorelasi}

Salah satu cara untuk mendeteksi masalah autokorelasi adalah dengan melihat nilai Durbin-Watson. Hasil uji autokorelasi dengan Durbin-Watson adalah sebagai berikut:

Tabel 5. Hasil Uji Uji Autokorelasi

\begin{tabular}{|l|c|r|r|r|r|}
\hline Model & $\mathrm{R}$ & $\begin{array}{c}\mathrm{R} \\
\text { Square }\end{array}$ & $\begin{array}{l}\text { Adjusted } \\
\text { R Square }\end{array}$ & $\begin{array}{l}\text { Std. Error of } \\
\text { the Estimate }\end{array}$ & $\begin{array}{r}\text { Durbin- } \\
\text { Watson }\end{array}$ \\
\hline 1 & $.546^{\mathrm{a}}$ & .298 & .254 & 2.45181 & 1.686 \\
\hline
\end{tabular}
a. Predictors: (Constant), X2, X1
b. Dependent Variable: Y

Sumber : Hasil Penelitian, diolah 2021

Dengan memperhatikan nilai DurbinWatson pada tabel 5 di aas menunjukkan nilai $\mathrm{d}=1,686$. Nilai tersebut berada diantara nilai $1,54<\mathrm{DW}<2,46$. Hal ini membuktikan bahwa nilai $\mathrm{d}>\mathrm{d}_{\mathrm{u}}$ sehingga dapat dikatakan bahwa dalam penelitian ini tidak terjadi autokorelasi pada persamaan regresi tersebut maka dapat disimpulkan bahwa dalam model regresi tersebut tidak terjadi autokorelasi antara sesama variabel independen.

\section{Uji Heteroskedastisitas}

Untuk menguji ada tidaknya masalah heterokedastisitas dapat dilakukan dengan melihat apakah terdapat pola tertentu pada 
Jurnal Manajemen dan Bisnis, Volume 3, No. 1, Juli 2021

grafik scatterplot antara SRESID dan ZPRED dimana sumbu Y adalah residual dan sumbu X adalah yang telah diprediksi.

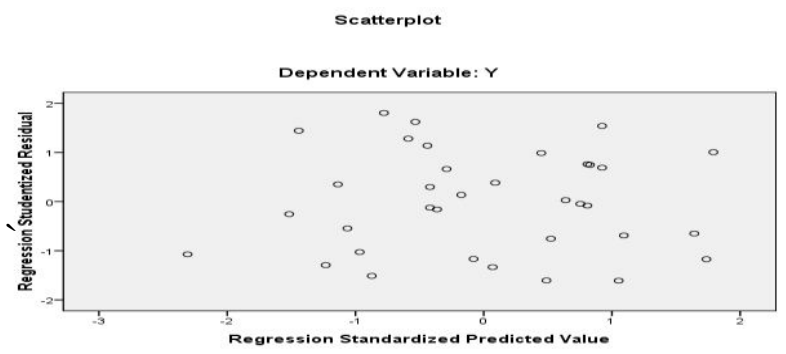

Gambar 1 : Grafik Scatterplot

Dari gambar diatas, terlihat bahwa Uji heterokedasitas dengan scatterplot menampakkan titik-titik yang menyebar secara acak dan tidak ada pola yang jelas terbentuk serta dalam penyebarannya titik-titik tersebut menyebar dibawah dan diatas angka 0 pada sumbu Y. Hal tersebut mengidentifikasikan bahwa tidak terjadinya heteroskedastisitas pada model regresi, sehingga model regresi layak dipakai untuk memprediksi variabel Kepuasan Kerja Pegawai

\subsection{Uji Prasyarat Analisis}

\section{Analisis Regresi Linier Berganda}

Ringkasan hasil analisis regresi liniear berganda dengan menggunakan software statistic SPSS adalah sebagai berikut:

Tabel 6. Regresi Linier Berganda Coefficients $^{\text {a }}$

\begin{tabular}{|c|c|c|c|c|c|}
\hline \multirow[b]{2}{*}{ Model } & \multicolumn{2}{|c|}{$\begin{array}{l}\text { Unstandardized } \\
\text { Coefficients }\end{array}$} & $\begin{array}{c}\text { Standardized } \\
\text { Coefficients } \\
\end{array}$ & \multirow[b]{2}{*}{$\mathrm{t}$} & \multirow[b]{2}{*}{ Sig. } \\
\hline & B & $\begin{array}{l}\text { Std. } \\
\text { Error }\end{array}$ & Beta & & \\
\hline (Constant) & 17.250 & 4.669 & & 3.695 & .001 \\
\hline $\mathrm{X} 1$ & .409 & .153 & .440 & 2.674 & .012 \\
\hline $\mathrm{X} 2$ & .147 & .132 & .183 & 1.113 & .274 \\
\hline
\end{tabular}

Sumber : Hasil Penelitian, diolah 2021
Dari tabel di atas dapat dibuat persamaan regresi berganda sebagai berikut :

$$
Y=17.250+0,409 X_{1}+0,147 X_{2}
$$

a. Konstanta $(\alpha)$ sebesar 17,250 memberikan pengertian bahwa jika lingkungan kerja non fisik (X1) dan disiplin kerja (X2) secara serempak atau bersama-sama tidak mengalami perubahan atau sama dengan nol (0) maka besarnya Semangat Kerja Pegawai (Y) bernilai 16.008 satuan.

b. Jika nilai b1 yang merupakan koefisien regresi dari lingkungan kerja non fisik (X1) sebesar 0,409 yang artinya mempunyai pengaruh positif terhadap variabel dependen (Y) mempunyai arti bahwa jika variabel lingkungan kerja non fisik (X1) bertambah 1 satuan, maka Semangat Kerja Pegawai (Y) juga akan mengalami peningkatan sebesar 0,409 satuan dengan asumsi variabel lain tetap atau konstan.

c. Jika nilai b2 yang merupakan koefisien regresi dari Disiplin Kerja (X2) sebesar 0,147 artinya mempunyai pengaruh positif terhadap variabel dependen (Y) dengan asumsi bahwa jika variabel Disiplin Kerja (X2) bertambah 1 satuan, maka Semangat Kerja Pegawai (Y) juga akan mengalami peningkatan sebesar 0,147 satuan dengan asumsi variabel lain tetap atau konstan

\section{Koefisien Korelasi Product Moment (R)}

Koefisien korelasi product moment (R) digunakan untuk mengetahui arah hubungan antara variabel dependen dengan variabel 
Jurnal Manajemen dan Bisnis, Volume 3, No. 1, Juli 2021

independen selain mengukur kekuatan asosiasi

(hubungan). Adapun hasil analisis koefisien korelasi ganda adalah sebagai berikut :

Tabel 7. Koefisien Korelasi (R)

\begin{tabular}{|l|c|r|r|r|r|}
\hline Model & $\mathrm{R}$ & $\begin{array}{c}\mathrm{R} \\
\text { Square }\end{array}$ & $\begin{array}{l}\text { Adjusted } \\
\text { R Square }\end{array}$ & $\begin{array}{l}\text { Std. Error of } \\
\text { the Estimate }\end{array}$ & $\begin{array}{r}\text { Durbin- } \\
\text { Watson }\end{array}$ \\
\hline 1 & $.546^{\mathrm{a}}$ & .298 & .254 & 2.45181 & 1.686 \\
\hline
\end{tabular}
a. Predictors: (Constant), X2, X1
b. Dependent Variable: Y

Sumber : Hasil Penelitian, diolah 2021

Dari tabel 7 di atas dapat diketahui bahwa nilai koefisien korelasi ganda yaitu sebesar $0.546(54,6 \%)$, artinya tingkat keeratan hubungan antara variabel lingkungan kerja non fisik dan disiplin kerja terhadap kepuasan kerja pegawai pada Camat Palibelo Kabupaten Bima berada pada tingkat keeratan hubungan yang sedang. Sesuai dengan pedoman interval koefisien korelasi berada interval 0,40 - 0,599 dengan tingkat hubungan yang cukup kuat.

\section{Koefisien Determinan $\left(\mathbf{R}^{2}\right)$}

Koefisien Determinasi bertujuan untuk melihat besarnya kontribusi atau besarnya pengaruh proporsi variasi perubahan variabel independen (variabel bebas) secara keseluruhan terhadap variabel dependen (variabel terikat). Hasil analisis koefisien determinasi yaitu :

Tabel 8. Koefisien Determinasi $\left(\mathrm{R}^{2}\right)$ Model Summary ${ }^{\text {b }}$

\begin{tabular}{lrrrr}
\hline Model & $\mathrm{R}$ & $\mathrm{R}$ Square & $\begin{array}{c}\text { Adjusted } \\
\text { R Square }\end{array}$ & $\begin{array}{c}\text { Std. Error of the } \\
\text { Estimate }\end{array}$ \\
\hline 1 & $.546^{\mathrm{a}}$ & .298 & .254 & 2.45181 \\
\hline a. Predictors: (Constant), X2, X1 & \\
b. Dependent Variable: Y
\end{tabular}

Sumber : Hasil Penelitian, diolah 2021
Nilai R-square pada tabel 8 di atas yaitu 0.298 atau sebesar $29,8 \%$ yang berarti sebesar 29,8 \% kontribusi atau pengaruh variabel lingkungan kerja non fisik (X1) dan disiplin kerja (X2) secara simultan (bersamasama) terhadap variabel Kepuasan kerja (Y), sedangkan sisanya sebesar 70,2 \% adalah pengaruh faktor lainnya yang tidak diteliti.

\section{Pengujian Hipotesis}

\section{a. Uji t (Uji Parsial)}

Uji statistik (Uji-T) pada dasarnya digunakan untuk melihat pengaruh variabel independen terhadap variabel dependen secara parsial. Hasil uji-t adalah sebagai berikut :

Tabel 9. Uji-t (Parsial)

\section{Coefficients $^{\text {a }}$}

\begin{tabular}{|c|c|c|c|c|c|}
\hline \multirow[b]{2}{*}{ Model } & \multicolumn{2}{|c|}{$\begin{array}{c}\text { Unstandardized } \\
\text { Coefficients }\end{array}$} & $\begin{array}{l}\text { Standardized } \\
\text { Coefficients } \\
\end{array}$ & \multirow[b]{2}{*}{$\mathrm{t}$} & \multirow[b]{2}{*}{ Sig. } \\
\hline & B & $\begin{array}{l}\text { Std. } \\
\text { Error }\end{array}$ & Beta & & \\
\hline (Constant) & 17.250 & 4.669 & & 3.695 & .001 \\
\hline $\mathrm{X} 1$ & .409 & .153 & .440 & 2.674 & .012 \\
\hline $\mathrm{X} 2$ & .147 & .132 & .183 & 1.113 & .274 \\
\hline
\end{tabular}

Sumber : Hasil Penelitian, diolah 2021

Hasil uji $\mathrm{t}$ antara lingkungan kerja non fisik (X1) dengan Kepuasan Kerja (Y) menunjukkan nilai sig. $\mathrm{t}=0,012$. Karena nilai signifikasi t $(0,012)<\alpha=0,05$ dengan nilai t-hitung $=$ 2,674 lebih besar dari nilai t-tabel = 1,6938 maka pengaruh lingkungan kerja non fisik (X1) terhadap disiplin kerja (Y) adalah positif dan signifikan. Hal ini berarti $\mathrm{H} 0$ ditolak dan $\mathrm{H} 1$ diterima sehingga dapat disimpulkan bahwa kepuasan kerja dapat dipengaruhi secara signifikan oleh Lingkungan 
Jurnal Manajemen dan Bisnis, Volume 3, No. 1, Juli 2021

kerja non fisik atau dengan meningkatkan Lingkungan kerja non fisik maka kepuasan kerja akan mengalami peningkatan.

Dari hasil penelitian ini menunjukkan bahwa rata-rata frekuensi jawaban item-item pada variabel lingkungan kerja non fisik adalah berkategori baik yang berarti pegawai setuju terhadap lingkungan kerja non fisik yang ada di perusahaan. Item atau indikator dalam penelitian ini yang paling berpengaruh adalah kenyamanan bekerja dengan antar rekan kerja, karena memiliki rata-rata kategori sangat baik, dan indikator dengan rataan nilai terendah namun masih dalam kategori baik adalah kesempatan pegawai untuk berkonsultasi mengenai pekerjaan yang dilakukan, dan penjelasan dari atasan mengenai pekerjaan yang akan dilakukan. Dengan adanya lingkungan kerja non fisikyang baik, pegawai akan merasa senang dan nyaman dalam bekerja. Oleh karena itu, perusahaan harus senantiasa memperhatikan lingkungan kerja non fisik pegawainya karena tanpa adanya lingkungan kerja non fisik yang baik, pegawai akan merasa tidak nyaman dan hal tersebut dapat mengganggu konsentrasi pegawai dalam bekerja.

Dari hasil penelitian ini menunjukkan bahwa rata-rata frekuensi jawaban item-item pada variabel lingkungan kerja non fisik adalah berkategori baik yang berarti pegawai setuju terhadap lingkungan kerja non fisik yang ada di Camat Palibelo. Item atau indikator dalam penelitian ini yang paling berpengaruh adalah kenyamanan bekerja dengan antar rekan kerja, karena memiliki rata-rata kategori sangat baik, dan indikator dengan rata-rata nilai terendah namun masih dalam kategori baik adalah kesempatan pegawai untuk berkonsultasi mengenai pekerjaan yang dilakukan, dan penjelasan dari atasan mengenai pekerjaan yang akan dilakukan. Dengan adanya lingkungan kerja non fisik yang baik, pegawai akan merasa senang dan nyaman dalam bekerja. Oleh karena itu, Kantor Camat Palibelo harus senantiasa memperhatikan lingkungan kerja non fisik pegawainya karena tanpa adanya lingkungan kerja non fisik yang baik, pegawai akan merasa tidak nyaman dan hal tersebut dapat mengganggu konsentrasi pegawai dalam bekerja. Penelitian yang dilakukan oleh Ni Nyoman Paramita Iswari Putri Pande (2013) menyebutkan bahwa adanya pengaruh yang positif dan signifikan antara lingkungan kerja non fisik dengan kepuasan kerja pegawai

Hasil uji t antara Disiplin Kerja (X2) dengan Kepuasan Kerja (Y) menunjukkan nilai sig.t sebesar 0,274. Karena nilai signifikansi t $(0,274)>\alpha=0,05$ dengan nilai thitung $=1,113$ lebih kecil dari nilai t-tabel. $=$ 1,6938 maka pengaruh Disiplin Kerja (X2) terhadap Kepuasan Kerja (Y) adalah poitif dan tidak signifikan. Hal ini berarti Ho diterima dan $\mathrm{H} 2$ ditolak sehingga dapat disimpulkan 
Jurnal Manajemen dan Bisnis, Volume 3, No. 1, Juli 2021

bahwa disiplin kerja tidak berpengaruh secara signifikan terhadap kepuasan kerja pegawai.

Berdasarkan hasil penelitian di atas tidak ada ada pengaruh yang signifikan antara disiplin kerja terhadap kepuasan kerja Arah hubungan yang positif dan tidak signifikan menunjukkan jika variabel disiplin kerja (X2) semakin baik maka variabel semangat kerja pegawai (Y) juga semakin meningkat. Hal ini sesuai dengan teori Nitisemito (2012), ketidakdisiplinan bukan hanya sekedar indikasi turunnya semangat dan kegairahan kerja tetapi dapat mempengaruhi efektivitas dan efisiensi pencapaian tujuan organisasi. Oleh karena itu apabila seorang pegawai sudah memiliki dasar kedisiplin yang kuat secara tidak langsung pegawai memiliki semangat kerja yang tinggi dan memberikan sikap yang positif seperti kesetiaan, kerja sama yang baik dan ketaatan pada kewajiban dan tugas.

\section{b. Uji-F (Pengujian Secara Simultan)}

Uji statistik F (imultan) menunjukkan apakah semua variabel bebas mempunyai pengaruh secara simultan (bersama-sama) terhadap variabel terikat. Hasil uji-F adalah sebagai berikut :

Tabel 10. Uji F Simultan

\begin{tabular}{|c|c|c|c|c|c|c|}
\hline \multicolumn{2}{|c|}{ Model } & \multirow{2}{*}{$\begin{array}{r}\begin{array}{r}\text { Sum of } \\
\text { Squares }\end{array} \\
81.523\end{array}$} & \multirow{2}{*}{$\frac{\mathrm{df}}{2}$} & \multirow{2}{*}{$\begin{array}{l}\text { Mean } \\
\text { Square } \\
40.761\end{array}$} & \multirow{2}{*}{$\frac{F}{6.781}$} & \multirow{2}{*}{$\frac{\text { Sig. }}{.004^{\mathrm{a}}}$} \\
\hline 1 & Regression & & & & & \\
\hline & Residual & 192.363 & 32 & 6.011 & & \\
\hline & Total & 273.886 & 34 & & & \\
\hline
\end{tabular}

a. Predictors: (Constant), X2, X1

b. Dependent Variable: Y

Sumber : Hasil Penelitian, diolah 2021
Berdasarkan tabel di atas diketahui bahwa nilai F-hitung adalah sebesar 6,781. Nilai F-hitung tersebut lebih besar dari nilai Ftabel 3,27 $(6,781>3,27)$ dengan nilai sig. Fhitung sebesar 0,004. Karena nilai sig. F $(0,004)<\alpha=0.05$ maka model analisis regresi adalah positif dan signifikan . Hal ini berarti H0 ditolak dan $\mathrm{H} 3$ diterima sehingga dapat disimpulkan bahwa lingkunan kerja non fisik dan disiplin kerja berpengaruh positif dan signifikan terhadap kepuasan kerja pegawai pada Kantor Camat Palibelo Kabupaten Bima.

Dengan lingkungan kerja non fisik yang kondusif mampu memberikan dorongan, dan dukungan untuk mencapai kepuasan kerja pegawai. Dengan dibantu oleh kedisiplinan pegawai terhadap pekerjaan yang teratur serta sikap dan perilaku seseorang itu tergantung dari kemauan/kesediaanya untuk bekerja dengan giat dan mempunyai tekad untuk mencapai tujuan yang diinginkan sehingga mampu meningkatkan kepuasan kerja pegawai. Maka disiplin kerja yang tinggi merupakan salah satu hal yang dapat meningkatkan kepuasan pegawai yaitu dengan usaha agar pegawai tetap sadar dan bersedia untuk patuh dan taat terhadap aturan yang ada sehingga dengan adanya kerelaan dari pegawai untuk disiplin terhadap aturan hal tersebut dapat meningkatkan kepuasan pegawai.

Pengaruh lingkungan kerja non fisik dan disiplin kerja terhadap kepuasan kerja pegawai sejalan dengan hasil penelitian yang dilakukan 
Jurnal Manajemen dan Bisnis, Volume 3, No. 1, Juli 2021

oleh Taiwo (2010) yang menemukan bahwa lingkungan kerja non fisik memiliki kontribusi yang besar terhadap kepuasan kerja dan produktivitas kerja pegawai. Dimana dengan lingkungan kerja non fisik dan disiplin kerja yang baik pegawai dapat lebih produktif dalam bekerja dan akan berdampak terhadap kepuasan kerja.

\section{KESIMPULAN DAN SARAN}

\subsection{Kesimpulan}

Berdasarkan hasil penelitian yang dilakukan sebagaimana telah dikemukakan dalam bab sebelum ini, maka dapatlah ditarik kesimpulan sebagai berikut :

1. Lingkungan kerja non fisik berpengaruh positif dan signifikan terhadap kepuasan kerja pegawai pada Kantor Camat Palibelo Kabupaten Bima. Nilai positif tersebut menunjukkan bahwa semakin kondusif lingkungan kerja non fisik pada Kantor Camat Palibelo Kabupaten Bima, maka kepuasan kerja pegawai akan terpenuhi. Begitu pula sebaliknya, semakin tidak kondusif lingkungan kerja non fisik, maka pegawai akan merasa tidak puas dalam bekerja

2. Disiplin kerja berpengaruh positif dan tidak signifikan terhadap kepuasan kerja pegawai. Nilai yang diperoleh dari analisis jalur menunjukkan variabel disiplin kerja terhadap kepuasan kerja pegawai memiliki pengaruh positif dan tidak signifikan
3. Lingkungan kerja non fisik dan disiplin kerja secara bersama-sama berpengaruh positif dan signifikan terhadap kepuasan kerja pegawai pada Kantor Camat Palibelo Kabupaten Bima. Dimana dengan lingkungan kerja non fisik dan disiplin kerja yang baik pegawai dapat lebih produktif dalam bekerja dan akan berdampak terhadap kepuasan kerja

\subsection{Saran}

1. Pimpinan harus senantiasa memperhatikan lingkungan kerja non fisik pegawainya karena tanpa adanya lingkungan kerja non fisik yang baik, pegawai akan merasa tidak nyaman dan hal tersebut dapat mengganggu konsentrasi pegawai dalam bekerja

2. Hal yang dapat diperhatikan dalam pencapaian kinerja yang tinggi adalah mengenai disiplin pegawai. Usaha yang perlu dilakukan organisasi yaitu agar seluruh pegawai dapat bekerja lebih efektif dan efisien. Pentingnya kerja satuan organisasi secara keseluruhan sangat tergantung kepada kinerja masing-masing pegawai secara perorangan, idealnya adalah masing-masing pegawai mampu melaksanakan apa yang menjadi tugasnya dengan benar sehingga semua berjalan sesuai dengan yang diharapkan, dan terciptalah pelayanan yang berkualitas

3. Hasil penelitian ini dapat digunakan sebagai acuan pada penelitian selanjutnya 
Jurnal Manajemen dan Bisnis, Volume 3, No. 1, Juli 2021

untuk menggali dan mempelajari variabel

lain yang berpengaruh terhadap kepuasan kerja

\section{DAFTAR PUSTAKA}

Arep, Ishak dan Hendri Tanjung. 2013. Manajemen Sumber Daya Manusia, Jakarta. Penerbit Universitas Trisakti:

Alex S, Nitisemito, 2013, Manajemen Personalia, JakartA : Ghalia Indonesia

Didit,Darmawan. 2013. Prinsip-Prinsip Perilaku Organisasi. Surabaya. PT. Temprina Media Grafika

Edy, Sutrisno, 2016, Manajemen Sumber Daya Manusia, Jakarta : Kencana Prenada Media Group.

Ghozali, Imam. 2016. Aplikasi Analisis Multivariete Dengan Program IBM SPSS 23 (Edisi 8). Cetakan ke VIII. Semarang : Badan Penerbit Universitas Diponegoro

Hasibuan S.P Malayu. 2014. Manajemen Sumber Daya Manusia. Jakarta: Bumi Aksara.

Handayani, Lisna. 2013. Pengaruh Lingkungan Kerja dan Kepuasan Kerja Pegawai Terhadap Disiplin Kerja Bidang Sekretariat Dinas Kehutanan Provinsi Sumatera Barat. Jurnal Pendidikan Ekonomi, 2 (4), 1-11.

Husein Umar. 2013. Metode Penelitian untuk Skripsi dan Tesis. Jakarta: Rajawali.

Mangkunegara A.A Anwar Prabu, 2012. Manajemen Sumber Daya Manusia. Bandung: PT.Remaja Rosdakarya.

Ma'arif dan Kartika. 2012. Manajemen Kinerja Sumber Daya Manusia. Bandung: PT. Penerbit IPB Press

Ni Nyoman Paramita Iswari Putri Pande. 2013. Pengaruh Kompensasi, Lingkungan Kerja Non Fisik, Dan Motivasi Kerja Terhadap Kepuasan Kerja Pegawai. Jurnal. Fakultas Ekonomi dan Bisnis Universitas Udayana (Unud), Bali, Indonesia.

Noor Rika Dinata Inbar, dkk, 2018. Pengaruh Lingkungan Kerja Terhadap Disiplin
Kerja Dan Semangat Kerja Pegawai (Studi Pada Pegawai PDAM Kota Malang). Jurnal Administrasi Bisnis (JAB) Vol. 58 No. 2.

Notoatmodjo. 2012. Pengembangan Sumber Daya Manusia. Jakarta. PT Rineka Cipta:

Nur Julian, Pamasang S. Siburian, dan Robiansyah. 2013. Pengaruh Hubungan Interpersonal dan Lingkungan Kerja Terhadap Kepuasan Kerja Pegawai Dinas Kebudayaan dan Pariwisata Prov. Kaltim. 1 (1)

Priansa, 2014. Perencanaan dan Pengembangan Sumber Daya Manusia. Bandung. Alfabeta.

Rivai, H. V., dan Sagala, E. J. 2011. Manajemen Sumber Daya Manusia untuk Perusahaan : dari Teori ke Praktik. Jakarta. Rajawali Pers.

Robbin \& Judge. 2015. Perilaku Organisasi Edisi 16. Jakarta. Salemba Empat.

Sedarmayanti. 2014. Manajemen Sumber Daya Manusia. Bandung: Refika Aditama.

Simamora, Henry, 2015. Manajemen Sumber Daya Manusia. Yogyakarta: STIEY.

Sugiyono. 2016. Metode Penelitian Kuantitatif, Kualitatif, dan Kombinasi (Mixed Methods). Bandung : Alfabeta

Suhandito, Tugas. 2013. Pengaruh Budaya Organisasi Dan Motivasi Terhadap Kinerja Pegawai Melalui Kepuasan Kerja Pegawai Pada RSUD Dr. Mohammad Saleh Probolinggo. Skripsi : Universitas Jember.

Sutardji, Gatot dan Martono, Engelbertus. 2014. Ilmu dan Seni Kepemimpinan. Bandung: Pustaka Rineka Cipta.

Taiwo, A.S. 2010. The Influence of work environment on workers productivity: A case of selected oil and gas industry in Lagos, Nigeria. African Journal of Business Management, Vol. 4 (3).

Wursanto. 2011. Dasar-Dasar Manajemen Personalia. Jakarta: Dian Pustaka. 